\title{
Review on Production and Marketing of Wheat in Ethiopia
}

\author{
Chernet Worku, Mamaru Abebe \\ Department of Agribusiness and Value Chain Management, Debre Markos University, Debre Markos, Ethiopia
}

\section{Email address:}

Chernetworku49@gmail.com (C. Worku)

\section{To cite this article:}

Chernet Worku, Mamaru Abebe. Review on Production and Marketing of Wheat in Ethiopia. International Journal of Agricultural Economics. Special Issue: Agribusiness and Value Chain Management. Vol. 5, No. 4, 2020, pp. 133-141.

doi: $10.11648 /$ j.ijae.20200504.16

Received: March 22, 2020; Accepted: April 30, 2020; Published: August 13, 2020

\begin{abstract}
Among the most important crops grown in Ethiopia wheat is one, both as a source of food and income generating venture for farmers in the country. Wheat and wheat products represent $14 \%$ of the total caloric intake in Ethiopia. Wheat is a cereal crop, which is produced in most parts of Ethiopia. Ethiopia is the second next to Egypt in Africa in wheat production which is 4.54 million tons. This study was aimed at reviewing wheat production and marketing in Ethiopia, with specific objectives of reviewing the wheat Production, supply and its Constraints in Ethiopia, major Marketing actors and function of wheat in Ethiopia, marketing structure, conduct and performance of wheat in Ethiopia as well as constraints and opportunities of wheat marketing in Ethiopia. The data were collected from secondary sources mainly from FAOSTAT, CSA and different published materials on wheat market chain in Ethiopia. The general idea of the review shows that Ethiopia has potential for wheat production but the two sides of agricultural constraints are production and marketing from the producer side faced with Rain failure, higher fertilizer price and delayed delivery, Soil erosion, Labor shortage, Lack of credit access, Lack of Draft power and Prevalence of crop diseases. On marketing side, lack of market information providing institutions, higher input price, multiple taxes, chemical herbicides adulteration, absence of road service, poor product quality and high cost of input, weak market linkages among market. In wheat marketing, the major actors identified during the review were; producers, farmer traders, urban assemblers, wholesalers, retailers, processors (millers, flour mill), consumers and commission agent. The market actors involved in different activities (wholesaling, retailing, assembly). Therefore, the government and other concerned bodies should focus on increasing production and productivity of wheat which in turn focused for establishing well wheat market development for mutual benefits of all actors.
\end{abstract}

Keywords: Wheat, Production, Marketing, Marketing Actors, Ethiopia

\section{Introduction}

In Africa wheat is one of the major cereals and a staple crop. Demand for wheat is increasing in Sub-Saharan Africa because of income growth, urbanization and dietary diversification [1]. However, Sub-Saharan countries, and Africa as a whole, produce only about $30 \%$ and $40 \%$ of their domestic requirements respectively causing heavy dependence on imports and making the region highly vulnerable to global market and supply shocks [1].

In Ethiopia wheat (Triticum sp.) is the fourth most important cereal food crop next to tef (Eragrostistef (Zucc.) Trotter), maize (Zea mays L.), and Sorghum (Sorghum bicolour (L.) Moench). National total production and productivity of wheat during 2011 were 2.86 million metric tons and $1.83 \mathrm{t} \mathrm{ha}^{-1}$, respectively [2]. Compared to world's productivity of $3.0 \mathrm{t} \mathrm{ha}^{-1}$, it is about $39 \%$ less [3]. The lower productivity is due to the prevalence of different abiotic and biotic stresses, e.g. low moisture stress [4], additionally Geleta and Grausgruber, [21] frost and low soil fertility, low yielding varieties, and head, leaf and stem diseases (in Ethiopia wheat is under production for centuries and today). Therefore, to increase the farmers production and productivity of wheat remove this problem by taking into account via training from agricultural extension sectors and grow wheat in cluster.

In Ethiopia, the estimated area of wheat cultivation was 1.7 million ha in 2013 production season, producing 4.04 million tons and the largest area coverage and total production in sub-Saharan Africa [5].

Wheat is produced by more than 4.7 million small scale farmers in Ethiopia; wheat is the 3rd in total production after 
teff and maize, and fourth in area coverage surpassed by teff, maize and sorghum [6]. Wheat production is steady increasing despite serious constraints such as recurrent epidemics of diseases, namely rusts and Septoria [6].

Wheat is among the most important crops grown in Ethiopia, both as a source of food and income generating venture for farmers in the country. Wheat and wheat products represent 14 percent of the total caloric intake in Ethiopia [5]. Therefore, wheat is the most important cereal crops that need much emphasis on its production and marketing.

The two sides of agricultural constraints are production and marketing. From production side, small holder farmers, particularly in developing country encounters multiple biotic and constraints abiotic such as inadequate capital, pests and diseases, poor access to improved germplasm, low labor productivity and unreliable climatic conditions and from marketing side low market price, poor marketing infrastructure, low market integration and this has led to low agricultural productivity and low supply of agricultural production to the market. The limited market participation of many agricultural household's face is a major constraint to combating poverty [7]. This shows that an efficient, integrated and responsive market that is marked with good performance is of crucial importance for optimal allocation of resources and stimulating households to increase output

Therefore, it is initiated to review wheat production and marketing for better understanding of the status of production of wheat and marketing of wheat and their actors in the case of Ethiopia. This review will help for generating the topic for improvement on the production and marketing situation of wheat in general as national or local level. Based on this, the following general and specific objectives were set outs for review of wheat production and marketing in Ethiopia.

Objectives of the Review

General Objective

The general objective of this review is to understand the Production and marketing of wheat in Ethiopia with the following specific objectives:

1) To Review wheat Production, supply and its Constraints in Ethiopia.

2) To Review major Marketing actors and function of wheat in Ethiopia

3) To review the marketing structure, conduct and performance of wheat in Ethiopia

4) To review the constraints and opportunities of wheat marketing in Ethiopia

\section{Methodology}

This seminar is reviewed by referring published documents, different studies, international journals and proceedings

\section{Review of Literatures}

\subsection{Definition or Theoretical Concepts}

Production: In agricultural, a stage of production can be referred to as any operating stage capable of producing a saleable product serving as an input to the next stage in the chain or for final consumption or use. A typical linkage of value chain include input supply, production, assembly, transport, storage, processing, wholesaling, retailing, and utilization, with exportation included as a major stage for products destined for international markets. A stage of production in a value chain performs a function that makes significant contribution to the effective operation of the value chain and in the process adds value [8].

Market: The term market has got a variety of meanings [9]. Defined markets are places where buyers and sellers come together to trade. They are social arrangements that allow buyers and sellers to obtain information and exchange commodities. In some cases the market may mean the place where buying and selling takes place, an arena in which a good is sold, a group of people carrying on buying or selling, or the commodity traded, such as the corn market, or time market [10]. Still another scholar [11]. defined market as "the exchange, circulation and distribution of commodities between people and places."

Marketing: The term marketing has a variety of meanings by various stake holders. All the concepts reflect the different aspects of the marketing process.

Market is defined as a point, or a place or sphere within which price making force operates and in which exchanges of title tend to be accompanied by the actual movement of the goods affected [12].

Market supply: The market supply refers to the amount actually taken to the markets irrespective of the needs for home consumption and other requirements. Whereas, the marketed surplus is the residual with the producer after meeting the requirement of seed, payment in kind, and consumption by farmer [13].

Market channel: The marketing channel is a trade or distribution network and it is defined by [14] as sets of interdependent organizations involved in the process of making the product or service available for consumption. The channel follows a vertical structure where products flow from producer to the ultimate consumer and in which actors meet at each market. Different marketers exist in channel arrangements to perform marketing functions that contribute to the product flow. Actors acting between producers and final users are known as intermediaries.

Marketing chain: Defines follow of commodity from producer to consumers that brings into place economic agents who perform complementary functions with the aim of satisfying both producers and consumers [15].

Market structure: Market structure is defined as characteristics of the organization of a market which seems to influence strategically the nature of competition by pricing behavior within the market [16]. Market structure is the description of the number and nature of participants in a market.

Marketing system: It is defined as the sequential set of kinds or types of business firms through which a product passes during the marketing process. It is the interrelationship of firms [17]. It is usually seen as a 
"system" because it comprises several, usually stable, interrelated structures that, along with production, distribution, and consumption, underpin the economic process [18].

Agricultural marketing: is defined as agriculturally oriented marketing. It embraces all operations and institutions involved in moving farm products from farm to consumers [19]. Agricultural marketing covers all the activities associated with the agricultural production and food, fiber assembly and feed, processing, and distribution to final consumers, including analysis of consumers' needs, motivations, and purchasing and consumption behavior [14].

\subsection{Ethiopian Wheat Production and Supply}

Wheat is a cereal crop, which is produced in most parts of the country, Ethiopia. Ethiopia is the second next to Egypt in Africa in wheat production which is 4.54 million tons in 2016 production year [20]

According to the Agricultural Sample Survey of 2014, there are 4.7 million wheat farmers in Ethiopia. Of these, more than three-quarters (78 percent) live in Oromia and
Amhara. SNNP accounts for 13 percent and Tigray 8 percent. Less than 1 percent of wheat farmers live in otherregions of Ethiopia. The average wheat area per farm is largest in Oromia, where farmers plant an average of 0.43 hectares/farm. This is partly the result of the large farms in Bale, Arsi, and West Arsi, the main wheat growing zones of the country. In contrast, the smallest areas cultivated with wheat are found in SNNP, where the average is just 0.19 ha/farm. The average wheat area in Amhara, Tigray, and other regions is between 0.28 and $0.39 \mathrm{ha} /$ farm. According to theoretical justification, male household heads supply more wheat to market than that of female because of better exposure to crop production, $85 \%$ were male and $15 \%$ were female.

The main wheat growing areas of Ethiopia are the highlands of the central, south-eastern and northwest parts of the country. In terms of regional contribution, the production of wheat originates from Oromia (57.4\%), Amhara (27\%), SNNP $(8.7 \%)$ and Tigray $(6.2 \%)$; and more than $41 \%$ of the annual wheat production comes from only three zones in Oromia and one in Amhara regions [21]

Table 1. Number of wheat producer farmers and average wheat area by Region.

\begin{tabular}{lllll}
\hline Region & wheat producer area $\mathbf{1 0 0 0}$ ha & number of wheat producers 1000s & \% & Average wheat produced area ha/farmer \\
\hline Tigray & 113 & 399 & $8 \%$ & 0.28 \\
Amhara & 530 & 1,742 & $37 \%$ & 0.30 \\
Oromia & 837 & 1,949 & $41 \%$ & 0.43 \\
SNNP & 118 & 636 & $13 \%$ & 0.19 \\
Other & 8 & 20 & $1 \%$ & 0.39 \\
National & 1,606 & 4,746 & $100 \%$ & 0.34 \\
\hline
\end{tabular}

Source: CSA, 2014.

According to FAOSTAT [19] estimates, Among SubSaharan country Ethiopia is the largest wheat producer in producing 3,000,000 MT. Wheat is commonlysow in the summer, before the meher (main) season rains in JuneSeptember, and then harvested in October-November. The majority $(59-75 \%)$ of wheat is grown in the region of Oromia, particularly the Arsi-Bale wheat belt that begins just north of Addis Ababa and extends to the south east. Amhara region is also a major producer, and these two regions accounted for $88 \%$ of domestic production in the $2006 / 07$ season.

\section{Wheat Production Constraint}

According to Mohammed [26] and Birhanu [13] there are different constraints that hinder or limit the production of wheat in Ethiopia. From these the major constrain are the following

Higher fertilizer price and delayed delivery: although application of fertilizer plays an important role for farmers to increase production and productivity, however price escalation of fertilizer together with limited access to credit has forced farmers to use lower quantity of fertilizer.

Soil erosion; Conserving the fertility of the soil plays positive role in increasing the production and productivity, thereby marketable surplus to flourish. On top of the technologies, like application of fertilizer that increase production, the protection of soil erosion which to maintain the already existed fertility of the soil plays a critical role in rising production.

Labor shortage: labor being a factor of production plays constructive role in increasing production and productivity of wheat. The absence of sufficient labor force in the family made some farmers to hire additional labors and others form labor cooperation with neighborhood farmers.

Lack of credit access: although the availability of credit is important source of cash for farmers to buy agricultural inputs needed to increase production of wheat.

Draft power: oxen are important power source of small holder farmers endowed with for production of agricultural crops.

Prevalence of crop diseases: prevalence of disease was one of the major production problems encountered by farmers in Ethiopia.

Diseases, especially rust diseases that frequently put high yielding improved varieties of bread wheat out of production, weeds especially grass weeds in wheat mono-cropping areas, low soil fertility that farmers cannot grow heat without application of chemical fertilizer sand/or compost, and shortage/unavailability of seed of improved variety. The other mentioned constraint was farmers in mechanized wheat production areas cannot get pure seed from own harvest due to varietal mixing during combine harvesting of farmers' fields after farmers' fields planted to different types of 
varieties. Similarly, combine harvesting of small-scale farmers' fields after farmers' fields aggravates spread of weed seeds from farm to farm was also a problem. less farmers awareness of improved crop management practices, high cost of combine harvesting since Sinana district farmers follow mechanized wheat production system, lack of credit, less availability and efficacy of many pesticides available in the market, untimely supply of fertilizers and shortage of capital to buy farm inputs were also remaining constraints explained by farmers as factors that affected production and productivity of wheat in the study area [25].

\subsection{Marketing of Wheat in Ethiopia}

Markets are important for economic growth and sustainable development of a given country, but, emphases in development policies in agrarian countries have usually been placed on increasing agricultural production to serve as a base for rural development. In the absence of wellfunctioning markets, agricultural production can experience several drawbacks [26].

The market supply refers to the amount actually taken to the markets irrespective of the needs for home consumption and other requirements. Whereas, the marketed surplus is the residual with the producer after meeting the requirement of seed, payment in kind, and consumption by farmer [13].

The efficient functioning of cereal markets is important given the significant share of cereals in food expenditures by households in low-income countries. Cereals comprise half of consumer food expenditures in Ethiopia, and about 75 percent of land area under cultivation [27].

Wheat marketing refers to the process by which wheat moves from farmers to consumers. However, most wheat in Ethiopia is not marketed; instead it is retained by the farmer and used for their own consumption, seed, and possibly other uses. According to the 2013/14 Agricultural Sample Survey, just 18 percent of wheat output was sold.

Wheat is produced mainly for consumption in Ethiopia and its trend is increasing. Besides its consumption, it also used for markets; it contributes to $80 \%$ of the total marketed quantity of cereal production; there is a large demand-supply gap. Smallholder farmers market their wheat produce only $20 \%$ of production and $80 \%$ of their total production are used for consumption; the per capital share of quantity consumed in pastoral areas, humid low highlands, small and large cities are $20 \%, 1 \%, 6 \%$ and $9 \%$ of all food consumptions respectively [28].

In Ethiopia, wheat markets have two supply sources this include-domestic production and import. Wheat is imported in large volumes as compared to other staple grains. On four years (2010-2014), Ethiopia imported on average 1.65 million metric tons of wheat commercially, which accounted about $50 \%$ of the domestic production during these periods. As imported wheat exclusively imported by the government with primary objectives of food price stabilization, the government has made effort to insulate the marketing channel of this administratively operated imported wheat from domestically produced and freely marketed wheat. Supply chain for imported wheat is relatively very short and largely dominated by few actors [29].

The Ethiopian wheat market exhibits high price variability. Prices generally follow the annual pattern of relatively low post-harvest prices in January followed by a period of rising prices that peak during the lean season (June to August), but are marked by significant intra-and inter- annual price changeability. Most of the wheat traders and brokers interviewed for this study also indicate that wheat price has been highly volatile over the past few years. While above half of the respondents report that wheat price varies on a weekly or monthly bases, the remaining key informants indicate that wheat prices exhibit inter-annual fluctuations [29].

The 2012 IFPRI-ATA Baseline Survey provides some useful information on the patterns of wheat sales by Ethiopian farmers. As shown in Table 2, on average wheat farmers produce $751 \mathrm{~kg}$ of wheat and sell $189 \mathrm{~kg}$, so that the marketed surplus ratio is 25 percent. The regional breakdown shows that Amhara has more wheat farmers, but the wheat production and wheat sales per farm are larger in Oromia. As a result, Oromia accounts for about half of all marketed wheat. Amhara is the second-largest supplier of marketed wheat, followed by SNNP and Tigray.

Table 2. Patterns of marketed surplus of wheat.

\begin{tabular}{llllll}
\hline Household Category & $\begin{array}{l}\text { \%o of household in } \\
\text { category }\end{array}$ & Wheat & $\begin{array}{l}\text { Sell as a \% of } \\
\text { Production }\end{array}$ & $\begin{array}{l}\text { Percentage share of } \\
\text { sales }\end{array}$ \\
\cline { 3 - 6 } Region & Production $\mathbf{( k g )}$ & Sales $\mathbf{( k g )}$ & 13 & 2 \\
\hline Tigray & 8 & 417 & 54 & 19 & 39 \\
Amhara & 56 & 709 & 310 & 33 & 50 \\
Oromia & 30 & 931 & 272 & 40 & 9 \\
SNNP & 6 & 679 & & & \\
\hline
\end{tabular}

Source: ATA. 2015, Wheat Supply Chain in Ethiopia

\section{Marketing Actors and Function of Wheat in Ethiopia}

In Ethiopia, different stakeholders or actors were involved in bringing wheat from the point of production (farm gate) till it reached the final destination (consumers). According to Mohammed [28] there are different market actors of wheat in Ethiopia among these the major actors are the following

These include farmers/producers, farmer traders, urban assemblers, wholesalers, retailers, processors (millers, flour mill), commission agent and consumer. The market actors involved in different activities (wholesaling, retailing, assembly).

Producers/farmers: these are marketing agents who participate both in production as well as marketing of surplus commodities they produce. They transport wheat to the nearest markets (village market) or regional markets by themselves, either using pack animals, or animal driven carts, 
or else medium-size Isuzu trucks, over an average distance of above 1 hours. They had several options to sell their product, selling directly or selling through broker to assemblers (rural and urban assemblers) and wholesalers.

Farmer trader/rural assemblers: Farmer traders/rural assemblers are farmers or part-time traders in the assembly markets who used to buy small quantity of wheat from farmers in village markets during slack period for the purpose of reselling it to consumers or wholesalers in either in rural or regional market. They use their financial resources and their local knowledge to buy wheat from the surrounding area.

Urban assembler: The assemblers play important role in the system of assembly. They consolidate the produce of individual farmers produce and prepare it for marketing. Assemblers not only know the areas of surplus well, but also speak the local language well. They also relieve their customers of the burden of quality by controlling the small quantities of wheat typically offered by farmers.

Brokers: these are agent middlemen who facilitate trades (buying and selling) between farmers and traders (wholesalers, urban assemblers, retailers), but does not usually physically handle products. These agents are not permanent brokers rather their main economic activity is farming during production season of the year. These intermediaries play important role in bringing farmers of their home residence sell their marketable surplus to the trader whom they undertook their brokerage activity.

Wholesalers: Wholesalers are major market participants of the marketing system who usually buy wheat of larger volume than any other actors in the marketing system and resell the products to urban retail merchants and processors than ultimate customers. Wholesalers reside in woreda market town and purchase wheat either through broker or directly from farmer or farmer trader or urban assemblers

Retailers: these market actors are located at the end of marketing chain, directly servicing the ultimate consumers of the marketing system. They perform numerous marketing functions such as buying, processing, storing, selling and other functions related to marketing. Based on their location of existence are classified as regional and urban retailers

Commission Agents: agent middlemen who physically handle products for buyers and sellers and paid for the service they delivered per quintal bases usually 2 to 3 birr per quintal both from buyer side as well as seller. They reside in terminal markets and do not invest their own capital. Cooperatives: these are farmers' service cooperative associations that supply agricultural inputs to farmers in time of production and buy farmers' agricultural output at harvest. Although existing service cooperatives received enough credits from Bureau of regional rural fund with interest rate of 1.5 percent, they are not efficient enough in terms of timely provisions of agricultural input, buying of their harvested products and financial management.

Consumers: are those who bought wheat and its products for consumption.

\subsection{Performance of Wheat Market in Ethiopia}

\subsubsection{Market structure of Wheat in Ethiopia}

Market structure is defined as characteristics of the organization of a market which seem to influence strategically the nature of competition and pricing behavior within the market. In agricultural marketing studies, market structural characteristics are used as a basis for classification of three categories of market: competitive, oligopolistic and monopolistic. It can be analyzed by the number of buyers and sellers within the system, degree market concentration, product differentiation, market integration, market transparency and or market information, and barriers to entry (licensing, capital limitations).

\section{(i) Market Concentration}

Market concentration which refers to number and size of distribution of sellers and buyers in the market, the firm's objectives, barriers to entry, economies of scale, and assumptions about rival firm's behaviors' are relevant in determining the degree of concentration and behaviors and performance [31] For an efficient market, there should be sufficient number of firms (buyers and sellers); firms of appropriate size are needed to fully capture economies of size; there should be no barriers to entry into and exit from the market and should have full market information [32].

The concentration ratio is expressed in terms of $\mathrm{CRx}$, which stands for the percentage of the market sector controlled by the biggest X firms. A CR4 of over $50 \%$ is generally considered as strong oligopoly; CR4 between $33 \%$ and $50 \%$ is generally considered a weak oligopoly and a CR4 of less than $33 \%$ is unconcentrated market Kohls and Uhl, (1985). According to Mohammed [26], the average market concentration of wheat (CR4) in Alaba Qulito Market of Halaba Special Woreda, Southern Ethiopia, is $71.5 \%$, which was oligopolistic market, indicating the existence of market imperfection. Similarly Sultan [31] revealed that the market concentration ratio of wheat in Sinana woreda, Ethiopia, was $88.7 \%$ of the total amount of wheat sold in market during peak production season at Robe town, indicated that the market structure is oligopoly market. In contrast to these, Hailu Negash [32] found that the market concentration ratio (CR4) of wheat in Mekele market, Tigray, was $22.31 \%$, indicates competitive market. Besides this other study reveal that the average market Concentration was $27.54 \%$, indicated that the market structure was weakly competitive markets [33]

\section{(ii) Barriers to Entry}

According to different authors, the following factors are the main barriers to enter and leave the wheat market in Ethiopia:

Skill (experience): The traders experience ranges from 4 up to 20 years with an average experience of 11.13 years. The existence of wider gap between traders indicated that experience was not a barrier to enter in to wheat trading [25].

License: trade license is obligatory for the wheat traders to enter the wheat market. But some wheat traders were not licensed because of the fear of high tax and costs incurred to get license card (initial capital), so that it is a great barrier to 
entry in the wheat market [25].

Capital: Working capital refers to the amount of money required by wheat traders to enter into the trading business. Fulfilling the initial capital requirement is compulsory for entry into wheat market. This means that large amount of start-up capital required for financing wheat trade operations is a needed. But for those who cannot afford it, cannot enter the wheat market that is why it is considered as a barrier to enter market [23].

\section{Product differentiation}

According to sultan [31], traders in the study area classified wheat into hard wheat and soft wheat and pay different prices. They used variety to classify wheat in to hard and soft wheat. The hard wheat was directly supplied to pasta and macoroni processing factory. Additionally, traders consider quality of seed (size), cleanness and season of production to afford different price for suppliers.

\subsubsection{Market Actor Conduct of Wheat in Ethiopia}

Price information is very important for wheat traders in the market. It is one of the main marketing strategies that cereal traders in Ethiopian use. Therefore, using special approach for obtaining market information (price information) is compulsory for wheat traders. In Ethiopia, price setting strategies of wheat are varied from one area to the other area. For example in the southern zone of Tigray, the traders, pursue an average of two markets on a weekly basis and use their cell phone to obtain the market information of grain including wheat [33].

Regarding to the attraction of their suppliers, the traders used different systems such as fair scale- weighing $(81.2 \%)$, giving better price relative to others $(8.24 \%)$, giving credit $(7.06 \%)$, and visiting their suppliers $(3.53 \%)$. The traders also used quality (good looking seed, free from foreign materials, well dried and preferred wheat varieties by their customers) as a strategy to attract buyers, which accounts about 88\% [34].

\subsubsection{Market Performance of Wheat in Ethiopia}

Marketing performance of wheat markets were analyzed by estimating the marketing margin, by taking into consideration associated marketing costs for key marketing channels. Basedon production costs and purchasing prices of the major market participants along the chain, margins at farmer, urban assemblers, wholesalers and urban retailer's levels were estimated and analyzed [30].

\section{Marketing Margin}

Marketing margins are the difference between prices of the two market actors. The term market margin is most commonly used to refer to the difference between producer prices of an equivalent quantity and quality of a commodity. However, it may also describe price differences between other points in the marketing chain, for example, between producer and wholesale, or wholesale and retail, prices [35]. The following table shows the average costs incurred by the different actors in wheat markets in Ethiopia.

Table 3. Marketing costs of wheat in Ethiopia.

\begin{tabular}{lllll}
\hline No. & Production cost (Birr/Qt) & Market costs (Birr/Qt) & Total cost (Birr/Qt) & Reference \\
\hline 1 & 260 & - & 260 & Elias et al., 2017 \\
2 & - & - & 169.56 & Mohammed, 2011 \\
Av. & 260 & 0 & 214.78 \\
\hline
\end{tabular}

Marketing margin is the difference between the price the consumers pay and the price the producers receive. Marketing margin is one of the commonly used measures of the performance of a marketing system. The different values of wheat marketing margin are depicted in the following table:

Table 4. Marketing margins of wheat in Ethiopia.

\begin{tabular}{|c|c|c|c|c|c|c|}
\hline \multirow{2}{*}{ Wheat marketing actors } & \multicolumn{3}{|l|}{ Sultan, 2016} & \multicolumn{3}{|c|}{ Mohammed, 2011} \\
\hline & SP (Birr/kg) & GMM (\%) & TGMM (\%) & SP (Birr/kg) & GMM (\%) & TGMM \\
\hline Producers & - & 80.75 & & 4.71 & 74.2 & \\
\hline Collector/Assembler & - & 0.57 & & 5.93 & 5.93 & \\
\hline Retailers & - & 0.69 & & 7.65 & 16.7 & \\
\hline Processors & - & 1.6 & & & & \\
\hline Average & - & 16.81 & 20.73 & 6.0825 & 25 & 25.8 \\
\hline
\end{tabular}

1) The average selling price of wheat in the country was $6.0825 \mathrm{birr} / \mathrm{kg}$.

2) The average growth marketing margin of wheat in the country was $20.91 \mathrm{birr} / \mathrm{kg}$

3 ) The average total growth marketing margin of wheat in the country was $23.365 \mathrm{birr} / \mathrm{kg}$

The profit margin of wheat is the margin which is obtained by subtracting total costs from total revenue. As shown in the following table, average profit margin of wheat that is obtained by producers is 333.83 birr/quintal.

Table 5. Total revenue of wheat.

\begin{tabular}{ll}
\hline item & wheat \\
\hline Average quintal produced (Qnt) & 19.05 quintal \\
Average price per quintal (SP) & 608.250 birr \\
Total cost (TC) & 274.78 birr \\
Total revenue (SP*Qnt) & $11,587.16$ birr \\
Net revenue (profit) [TR-TC] & $11,312.383$ birr/19.05 quintal = for \\
& farmers \\
\hline
\end{tabular}

Source: Mohammed, 2011; Elias et al., 2017; Sultan, 2016 


\subsection{Constraint and Opportunity of Wheat Marketing in Ethiopia}

The small-scale farmer does not have an insurance mechanism that safeguards its harvest from natural hazards, such as unwanted rain. Due to the above problems farmers supply different quality products to actors involved in wheat business in the study area. Traders collect their merchandise from different sources, places and individuals and don't have quality standards. What traders tend to do is to purchase any quantity from anyone offering the same price for whatever quality or offering a lesser price for inferior quality products. After purchasing, the traders then don't pack the products they have collected in accordance with the different grades of quality. Rather they tend to mix up the good and bad quality grains together and sell it at the price of good quality as the prevailing price doesn't give quality premium. Traders do this for two reasons, one they increase their profit margin and secondly because buyers are unable to check the quality and pay quality price for quality produce.

Market participation of wheat producers is affected by a series of factors including the volume of wheat production/ land and wealth status of producers. A study by [36], for instance, found that farmers with smallest farms (those with less than 0.5 hectares) sell just 9 percent of their harvest, on average, while those with more than 5 hectares sell an average of 39 percent of their wheat output. Only 3 percent of farmers fall into this category; however, so they contribute just 12 percent of the total marketed surplus of wheat. On the other hand, farmers with 2-5 hectares of land sell a smaller share ( 28 percent) but account for more than half ( 55 percent) of wheat marketed in Ethiopia because they are more numerous (accounted about 34 percent of the wheat producing farms) [35].

The distribution of imported wheat is also seasonal, with most of the wheat delivered between May and October, the six months prior to the beginning of the major wheat harvest. This aims to smooth out the supply of wheat in the domestic market, dampens the seasonality of wheat prices and reduces the cost of subsidies to wheat import [35].

In addition to these According to Mohammed [26] and Gebremeske [20] the following are the main constraint and opportunity occurs in Ethiopia wheat market

Table 6. Constraint and Opportunity of Wheat Marketing in Ethiopia.

\begin{tabular}{ll}
\hline Opportunity of wheat market & Constraint of wheat market \\
\hline Suitability of the area for production & Lack of market information providing institutions \\
Government suitable agricultural policies designed to support farmers & Multiple Taxes \\
expansion of establishment of food processing plants & Higher input price \\
Increasing demand & Chemical herbicides adulteration \\
& absence of road service \\
& Poor product quality and high cost of input \\
& Weak market linkages among market participants \\
\hline
\end{tabular}

\section{Conclusion and Recommendations}

\subsection{Conclusion}

Generally, wheat is major staple grain which produced in the highlands of Ethiopia and cultivated by small holders in every region of the country. The main wheat growing areas of Ethiopia are the highlands of the central, south-eastern and northwest parts of the country. In terms of regional contribution, the production of wheat originates from Oromia (57.4\%), Amhara (27\%), SNNP (8.7\%) and Tigray (6.2\%); and more than $41 \%$ of the annual wheat production comes from only three zones in Oromia and one in Amhara regions. Based on CSA and ASS data Ethiopia is the second next to Egypt in Africa in wheat production which is 4.54 million tons, there are 4.7 million wheat farmers in Ethiopia. Of these, more than three-quarters ( 78 percent) live in Oromia and Amhara. SNNP accounts for 13 percent and Tigray 8 percent. The main market participants or actors of wheat are farmers/producers, farmer traders, urban assemblers, wholesalers, retailers, processors (millers, flour mill), commission agent and consumer. The market actors involved in different activities (wholesaling, retailing, assembly). The small-scale farmer does not have an insurance mechanism that safeguards its harvest from natural hazards, such as unwanted rain. Due to the above problems farmers supply different quality products to actors involved in wheat business in the study area. Traders collect their merchandise from different sources, places and individuals and don't have quality standard. The major constraints of wheat marketing involve poor storage and handling and low upgrading strategies to the commodity. Moreover, the major constraints identified as factors that affect wheat marketing are lack of market information providing institutions, higher input price, multiple taxes, and chemical herbicides, adulteration, absence of road service, poor product quality and high cost of input, weak market linkages among market.

\subsection{Recommendation}

I) The amount of wheat produced is one of the major issue that affect volume of wheat supplied to the market positively. Therefore, the government and other encouraging organization should focus on increasing production and productivity of the wheat.

II)For wheat production and marketing the following policy measures were recommended. The production and productivity of wheat is constrained by different 
factors as listed in the conclusion parts, therefore, research on wheat production that affects yields should be done by researcher's and the possible solutions should be put down accordingly.

III)The review of this study has shown that access to market information affected the quantity of wheat supplied positively and significantly. Farmers do not get timely market information's up on which to base their marketing decision. They depend on traders and other farmer friends for price information. Therefore, there has to be an institution that can convey reliable and timely market information required by all stakeholders simultaneously. This would make the marketing system to operate efficiently and harmoniously. The availability of timely and precise market information increases producers' bargaining capacity to negotiate with buyers of their produce. In order to obtain this advantage there is a need to improve extension system which focused on market extension and linkage of farmers with markets is necessary to ensure a reliable market outlet for producers in Ethiopia.

\section{References}

[1] Negassa, A., B. Shiferaw, Jawoo Koo, K. Sonder, M. Smale, H. J. Braun, S. Gbegbelegbe, ZheGuo, D. Hodson, S. Wood, T. Payne, and B. Abeyo. 2013. The Potential for Wheat Production in Africa: Analysis of Biophysical Suitability and Economic Profitability. Mexico, D. F.: CIMMYT.

[2] CSA (Central Statistical Agency), 2014. Agricultural sample survey report on area and production of major crops. Statistical Bulletin (532), Volume VI, Addis Ababa, Ethiopia. CSA (Central Statistical Agency). 2011. Agricultural Sample Survey. Reportonarea and Production of Major Crops: Private Peasant Holdings, Meher.

[3] OECD-FAO (Organization for Economic Co-operation and Development - Food and Agricultural Organization). 2011. Agricultural Outlook, 2011-2020. OECD-FAO 2011.

[4] Girma, B., Gelalcha, S. and Alemayehu, Z. 2001. Drought tolerance of some bread wheat in Ethiopia. Afr. Crop Sci. J. 9: 385-392.

[5] Abbot, J. C. and J. P. Makeham, 1981. Agricultural Economics and Marketing in the Tropics. Wing Tai Cheung Printing Co. Ltd, Rome. 58p.

[6] Amentae, T. K., Hamo, T. K., Gebresenbet, G. and Ljungberg, D., 2017. Exploring wheat value chain focusing on market performance, post-harvest loss, and supply chain management in Ethiopia: the case of Arsi to Finfinnee market chain. Journal of Agricultural Science, 9 (8), p. 22.

[7] Anandajayasekeram, P. and Berhanu Gebremedhin. 2009. Integrating innovation systems perspective and value chain analysis in agricultural research for development: implications and challenges. Improving Productivity and Market Success (IPMS) of Ethiopian farmers project working paper 16. ILRI (International Livestock Research Institute), Nairobi, Kenya.

[8] Ashenafi, A., 2010. Analysis of Grain Marketing in Southern
Zone of Tigray Region, Ethiopia.

[9] (Doctoral dissertation, Mekelle University). ATA. 2015. Agricultural Transformation Agency.

[10] Backman T. and R. Davidson. 1962. Marketing principle. The Ronal Presses Co., New York. Pp 3-24.

[11] Berhane, G., Paulos, Z., Tafere, K. and Tamru, S., 2011. Food grain consumption and calorie intake patterns in Ethiopia. IFPRI Ethiopia Strategy Support Program II (ESSP II) Working Paper, 23.

[12] Best R, Ferris S, Schiavone A. 2005. Building linkages and enhancing trust between small-scale rural producers, buyers in growing markets and suppliers of critical inputs. In Beyond agriculture making markets work for the poor. Proceedings of an International Seminar28: 19-50.

[13] Birhanu Bayeh. 2010. Assessment of Bread Wheat Production, Marketing and Selection of N- Efficient Bread Wheat (Tritiumaestivum L.) Varieties for Higher Grain Yield and Quality in North Western Ethiopia. M.Sc thesis submitted to the School of Graduate Studies, Bahir Dar University.

[14] Branson, R. E. and Norvell, N. 1983. Introduction of Agricultural Marketing, McGraw Hill Book Company, New York. 365p.

[15] Cramer, G. L. and Jensen, W., 1982. Agricultural Economics and Agribusiness, $2^{\text {nd }}$ Edition. McGraw Hill Book Company, USA. $222 p$.

[16] CSA (Central Statistical Agency of Ethiopia), 2017. Agricultural Sample Survey. Report on Area and Production of Major Crops.

[17] CSA (Central Statistical Authority), 2013. Agricultural sample survey report on area and production of crops (private peasant holdings, meher season). Volume I. CSA, Addis Ababa, Ethiopia.

[18] FAO (Food and Agricultural Organization). 2003. FAO action program for the prevention of food loses. Milk and dairy products, post harvest loses and food safety in sub-Saharan Africa and the near east. Regional approaches to national challenges. Synthesis report. ILRI, Nairobi, Kenya.

[19] FAO (Food and Agriculture Organization).2015. Food Balance Sheets FAOSTAT. Rome. FAO, 2013. Crop Water Information: Wheat. FAO (WWW Document). FAO. 2012. GIEWS Country Brief on Ethiopia. Retrieved from FAOSTAT. 2015. Area and Production of wheat.

[20] Gebremeskel Desalegn, Jayne, T. S., and Shaffewr, J. D, 1998. Market structure, conduct, and performance: constraints on performance of Ethiopia grain markets. Grain market research project, Addis Ababa. Working Paper 8.

[21] Geleta, N. and Grausgruber, H. 2009. Phenotypic diversity of tetraploid Ethiopian wheat landraces. p 72, In: Meglic, U., and Bastar, M. T. (eds.). 19th EUCARPIA Conference, Genetic Resources Section, May 26-29, Ljubljana, Slovenia, Book of Abstracts. Agricultural Institute of Slovenia, Ljubljana. Ethiopia. Afr. Crop Sci. J. 9: 385-392.

[22] Islam, M. S., Miah, T. H. and Haque, M. M., 2001. Marketing system of marine fish in Bangladesh. Bangladesh Journal of Agricultural Economics. 24, (1 and 2): 127-142. Bangladesh. Bangladesh Journal of Agricultural Economics. 24, (1 and 2): 127-142. 
[23] Jayne, T. S., N. Mason, R. Myers, J. Ferris, D. Mather, M. Beaver, N. Lenski, A. Chapoto and D. Boughton. 2010 (a). Patterns and Trends in Food Staples Markets in Eastern and Southern Africa: Toward the Identification of Priority Investments and Strategies for Developing Markets and Promoting Smallholder Productivity Growth. MSU International Development Working Paper No. 104. Department of Agricultural, Food and Resource Economics, Department of Economics. East Lansing: Michigan State University.

[24] Larson, A. L. 1957. Agricultural Marketing. Prentice-Hall. New York, USA.

[25] Mendoza G. 1995. A primer on marketing channels and margins. Lyme Rimer Publishers Inc., USA. 425p.

[26] Mohammed Urgessa. 2011. Market chain analysis of teff andwheat production in Halaba special woreda, Southern Ethiopia. M.Sc thesis submitted to the School of Graduate Studies, Haramaya University.

[27] Nicholas Minot, James Warner, Solomon Lemma, Leulsegged Kasa, Abate Gashaw, Shahidur Rashid international Food Policy Research Institute, Markets, Trade, and Institutions Division.

[28] Samuel Gebreselassie, Mekbib G. Haile, Matthias Kalkuhl. 2017. The Wheat Sectorin Ethiopia: Current Statusand Key Challenges for Future Value Chain Development. working pepare $\mathrm{p}$ 19-22.
[29] Schere, F. M. 1980. Industrial Market Structure and Economic Performance. $2^{\text {nd }}$ Edition. R and McNally College Publishing Agency, USA. 342p.

[30] Singh, R. P., D. P. Hodson, J. Huerta-Espino, Y. Jin, P. Njau, R. Wanyera, S. A. Herrera-Foessel, R. W. Ward. 2008. Willstem rust destroy the world's wheat crop? Advancesin Agronomy, 98: 271-309.

[31] Sultan Usman Mahamud. 2016. Analysis of Wheat Value Chain: The Case of Sinana District, Bale Zone, Oromia Region, Ethiopia. M. Sc thesis submitted to the School of Graduate Studies, Haramaya University.

[32] Tadesse, A., 2011. Market chain analysis of fruits for Gomma Woreda, Jimma zone, Oromia National Regional State (Doctoral dissertation, Haramaya University).

[33] Teferi, T. A., Z. S. Gebreslassie. 2015. Occurrence and intensity of wheat Septoriatritici blotch and host response in Tigray, Ethiopia. Crop Protection, 68: 67-71.

[34] USDA, 2013. Ethiopia Grain and Feed Annual Report, Global Agricultural Network Information, GAIN report number ET1301.

[35] Wolday, Amha, 1994. Food Grain Marketing Development in Ethiopia after Reform 1990, A Case Study of Alaba Siraro, The PhD Dissertation Presented to Verlag Koster University. Berlin 293p Organization, (2011). 